\title{
Involvement of a Fishing Community in the Eradication of the Introduced Cactus Mouse (Peromyscus eremicus cedrosensis) from San Benito Oeste Island, Mexico
}

\author{
Federico Méndez Sánchez ${ }^{1,2, *(\mathbb{D})}$, Alfonso Aguirre-Muñoz ${ }^{1}$, Araceli Samaniego ${ }^{1,+}$, Yuliana Bedolla Guzmán ${ }^{1}$, \\ Ana Cárdenas Tapia ${ }^{1}$, Evaristo Rojas Mayoral ${ }^{1}$ (D), Mariam Latofski Robles ${ }^{1}$, Patricia Koleff ${ }^{3}$ (D), \\ Aradit Castellanos Vera ${ }^{2}$, Gustavo Arnaud Franco ${ }^{2}$, Luis Felipe Beltrán Morales ${ }^{2}$ and Alfredo Ortega-Rubio ${ }^{2}$ (D)
}

check for updates

Citation: Méndez Sánchez, F.; Aguirre-Muñoz, A.; Samaniego, A.; Bedolla Guzmán, Y.; Cárdenas Tapia, A.; Rojas Mayoral, E.; Latofski Robles, M.; Koleff, P.; Castellanos Vera, A.; Arnaud Franco, G.; et al. Involvement of a Fishing Community in the Eradication of the Introduced Cactus Mouse (Peromyscus eremicus cedrosensis) from San Benito Oeste Island, Mexico. Diversity 2021, 13, 588 https://doi.org/10.3390/d13110588

Academic Editor: Stuart Kininmonth

Received: 31 October 2021

Accepted: 17 November 2021

Published: 18 November 2021

Publisher's Note: MDPI stays neutral with regard to jurisdictional claims in published maps and institutional affiliations.

Copyright: (c) 2021 by the authors. Licensee MDPI, Basel, Switzerland. This article is an open access article distributed under the terms and conditions of the Creative Commons Attribution (CC BY) license (https:/ / creativecommons.org/licenses/by/ $4.0 /)$.
1 Grupo de Ecología y Conservación de Islas, A.C. (GECI), Ensenada 22800, Baja California, Mexico; alfonso.aguirre@islas.org.mx (A.A.-M.); SamaniegoA@landcareresearch.co.nz (A.S.); yuliana.bedolla@islas.org.mx (Y.B.G.); ana.cardenas@islas.org.mx (A.C.T.); evaristo.rojas@islas.org.mx (E.R.M.); mariam.latofski@islas.org.mx (M.L.R.)

2 Centro de Investigaciones Biológicas del Noroeste, La Paz 23096, Baja California Sur, Mexico; arcas04@cibnor.mx (A.C.V.); garnaud04@cibnor.mx (G.A.F.); lbeltran04@cibnor.mx (L.F.B.M.); aortega@cibnor.mx (A.O.-R.)

3 Comisión Nacional para el Conocimiento y Uso de la Biodiversidad, Ciudad de México 14010, Tlalpan, Mexico; pkoleff@conabio.gob.mx

* Correspondence: federico.mendez@islas.org.mx; Tel.: +52-6461734943 or +52-6461734997

† Present Address: Manaaki Whenua-Landcare Research, Auckland 92170, New Zealand.

Abstract: San Benito Archipelago is internationally important for the conservation of 13 species of seabirds. San Benito Oeste, the largest and only inhabited island, was declared mammal-free in 2000 after a series of eradications conducted in collaboration between the fishing cooperative Pescadores Nacionales de Abulón, the Mexican conservation organization, Grupo de Ecología y Conservación de Islas, A.C., and the Mexican Government. The archipelago remained mammal-free until 2006, when an unusual invader, the Cedros island cactus mouse (Peromyscus eremicus cedrosensis), was accidentally introduced to San Benito Oeste island. The same collaboration scheme involving locals, conservationists, and authorities was once again put in motion, delivering tangible results. Research informed the mouse eradication strategy, the local community supported the operation, and the mouse eradication was successfully implemented in December 2013. To date (8 years later), no mammals have been recorded in the archipelago, which suggests community-led island biosecurity is working. In addition, this collaborative restoration work contributed to the creation of the Baja California Pacific Islands Biosphere Reserve, protecting 21 islands, including the San Benito Archipelago, and 97 islets in the Mexican Pacific.

Keywords: invasive mammals; islands; rodents; biosecurity; local community; fishermen; conservation; restoration; Pacific Ocean

\section{Introduction}

Islands are key sites of biodiversity and key breeding sites for seabirds [1-3]. Mexico is home to a third (126 spp.) of the world's 368 seabird species [4,5]; the Baja California Pacific Islands are important seabird sites of regional and global relevance [6,7]. Invasive alien species are among the greatest threats to seabirds, affecting $165(45 \%)$ of the 364 species of seabirds worldwide, with most seabirds (70\%) facing multiple threats [4,5]. Invasive mammalian predators, such as rats (Rattus spp.) and cats (Felis catus) are the most damaging globally [8]. Rodents alone are responsible for 30\% (75 species) of all modern bird, mammal and reptile extinctions [8], and are also implicated in $84-86 \%$ of all extinctions on islands worldwide [8,9]. In Mexico, black rats (R. rattus) and cats have been the main reason for $71 \%$ of all land vertebrate extinctions, all insular species (i.e., 9 birds 
and 8 mammals) [10,11]. Fortunately, the eradication of invasive mammalian predators has been a successful conservation tool for decades [12,13], with projects being implemented on increasingly large and complex settings, including inhabited islands $[14,15]$. Eradications of invasive mammals have greatly benefitted seabirds [16-18].

Over two decades, Mexico has successfully eradicated 60 populations of invasive mammals from 39 islands [10,11], including the eradication of 16 rodent populations $(12 R$. rattus, 3 Mus musculus, 1 Peromyscus eremicus) from 15 islands, ranging in size from 2 to 539 ha $[19,20]$. Mexico stands out in the number of islands restored, notably conducting almost half $(45 \%)$ of the projects on inhabited islands, in all cases with the consent of local communities, and in many with their active participation [21].

The San Benito Archipelago (SBA), off the Baja California Peninsula, comprises three islands. The largest, San Benito Oeste (SBO), is inhabited by fishermen from the fishing cooperative Pescadores Nacionales de Abulón (PNA). PNA supports and participates in island restoration projects [21,22]. For example, PNA backed and provided logistical support for the eradication of European rabbit (Oryctolagus cuniculus), donkey (Equus asinus) and goat (Capra hircus) conducted on SBO by the Mexican conservation organization Grupo de Ecología y Conservación de Islas, A.C. (GECI) in 1998-1999, which benefited the native vegetation, including threatened species $[10,11,23]$. Thanks to these efforts, by 2000 the SBA was free of invasive mammals. In 2006, PNA alerted GECI about an introduced rodent on SBO, noting that they believed rodents were accidentally introduced during their fishing operations when fishermen arrived from Cedros to SBO in December 2006. Since the beginning, PNA communicated their commitment to help removing the rodents. In 2007, GECI confirmed the cactus mouse (Peromyscus eremicus cedrosensis), an endemic subspecies from nearby Cedros Island, had been introduced to SBO but not to the other islands. To avoid further invasions and to protect the whole archipelago's biodiversity, the eradication of the cactus mouse became a new collaborative project. Most seabirds on SBO are small burrowing species; therefore, they are highly susceptible to disturbance by mice.

Here, we describe the eradication project and, particularly, how PNA contributed to the detection of the mice, planning and supporting the operation, and their ongoing implementation of an active biosecurity program.

\section{Materials and Methods}

\subsection{Study Site}

The SBA is located in the Pacific Ocean, off the central portion of the Baja California peninsula (Figure 1). It comprises three islands: SBO (400 ha); San Benito Medio (SBM, $45 \mathrm{ha}$ ); and San Benito Este (SBE, $146 \mathrm{ha}$ ). These islands are washed by the California Current System, which has significant influence on the region's marine productivity and, thus, its seabird populations [24,25]. These islands feature remarkable biodiversity and are part of the protected area Reserva de la Biosfera Islas del Pacifico de la Península de Baja California, created in December 2016, managed by the federal government through the National Commission of Natural Protected Areas (CONANP) [22,26]. These islands are of continental origin and feature an arid climate. The dominant vegetation is maritime desert scrub [27]. They support 51 species of plants and 80 vertebrate species, including one endemic reptile (San Benito side-blotched lizard, Uta stellata), four pinnipeds (Guadalupe fur seal, Arctocephalus philippii townsendi; Northern elephant seal, Mirounga angustirostris; Harbor seal, Phoca vitulina; and California sea lion, Zalophus californianus) and 75 birds [27-29]. Native terrestrial mammals have never been recorded [29]. The SBA is an Important Bird Area (IBA) and is of central ecological importance for seabirds in the region [6,7,30-35]. Of all the Pacific islands off the Baja California Peninsula, the SBA has the greatest number of breeding seabirds with 13 species, and also the highest number of breeding pairs at 281,285 (CI $95 \%$ : 657-634,988) on average between 2014-2019, with cassin's auklet (Ptychoramphus aleuticus) and three storm-petrels (Leach's storm-petrel, Hydrobates leucorhous; black storm-petrel, H. melania; and least storm-petrel H. microsoma) the most 
abundant species [6]. To date, the SBA remains the largest and most seabird species-diverse colony in all the US and Mexico Pacific islands $[6,7]$.

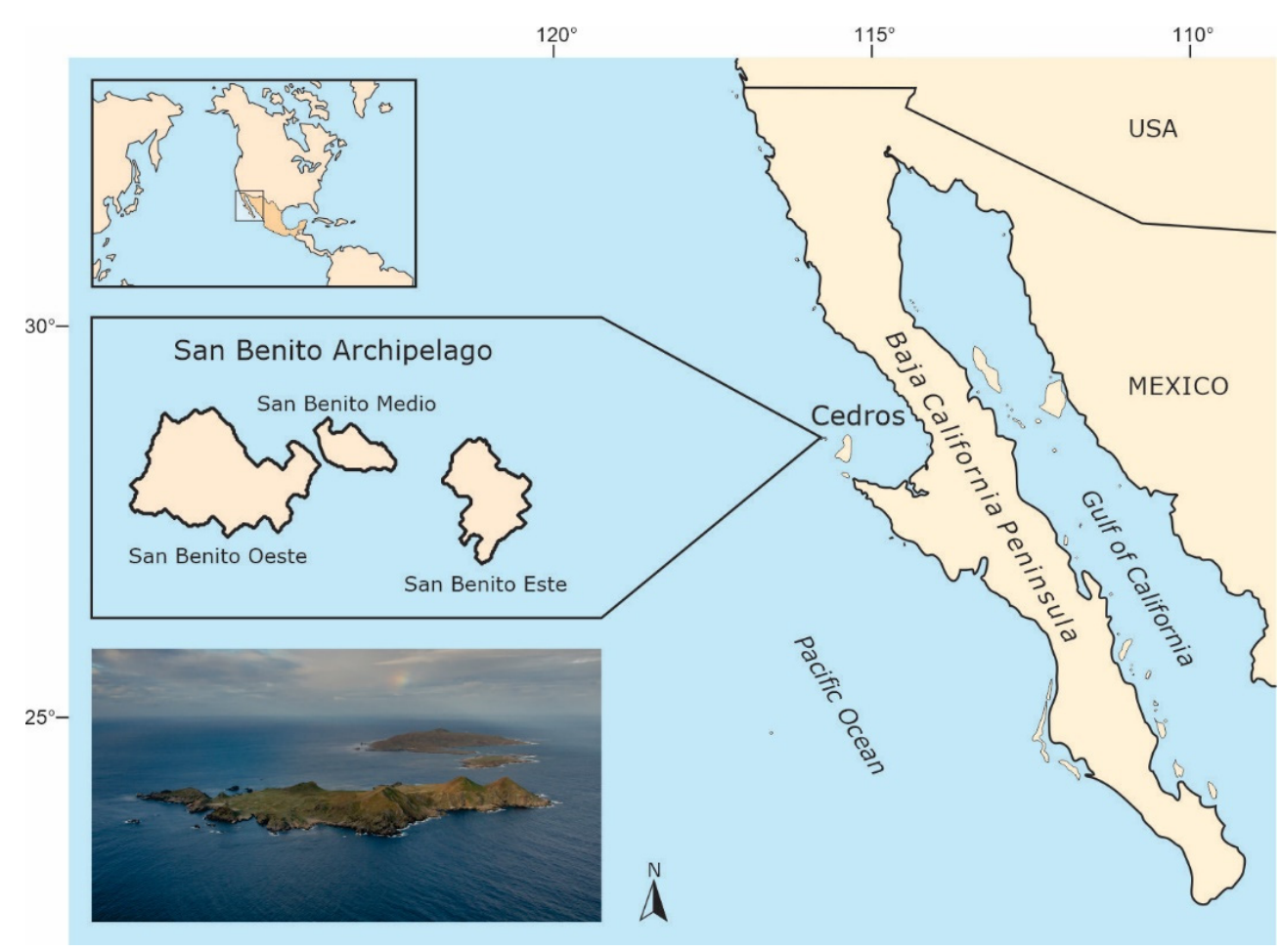

Figure 1. Location of the San Benito Archipelago in the Mexican Pacific off the Baja California Peninsula. The photo is an aerial panoramic view of the archipelago with San Benito Oeste Island in the foreground. Photo: (c) GECI/J.A. Soriano.

\subsection{PNA}

PNA was founded in 1943 and has been harvesting abalone (Haliotis spp.) and lobster (Panulirus interruptus) in the waters around Cedros Island (located $40 \mathrm{kms}$ east of SBO) and the SBA ever since. PNA has received long-term leases, granted by Mexico's federal government, conferring exclusive fishing rights within a well-defined area surrounding the islands. PNA is part of a regional federation of cooperatives, Federación Regional de Sociedades Cooperativas de la Industria Pesquera Baja California (FEDECOOP), that oversees the cooperatives' interests [36,37]. Since 2004, the FEDECOOP cooperatives have had their spiny lobster fishery certified as sustainable by the Marine Stewardship Council (MSC) [38-40]. The lobster fishery was the first in Mexico and Latin America, as well as the first artisanal lobster fishery in the world, to obtain MSC certification [36,40].

SBO harbors a small PNA fishing village (ca. 20 constructions) located in its southern east portion, which between 10-60 people inhabit throughout the year (Figure 2). The whole island, including the land where the fishing village is located, is owned by Mexico's federal government, although the existing infrastructure and its maintenance and improvement has received investment from PNA. Peak season of human presence and activity on SBO is during the abalone harvest (January to July) and lobster season (mid-September to mid-February). 


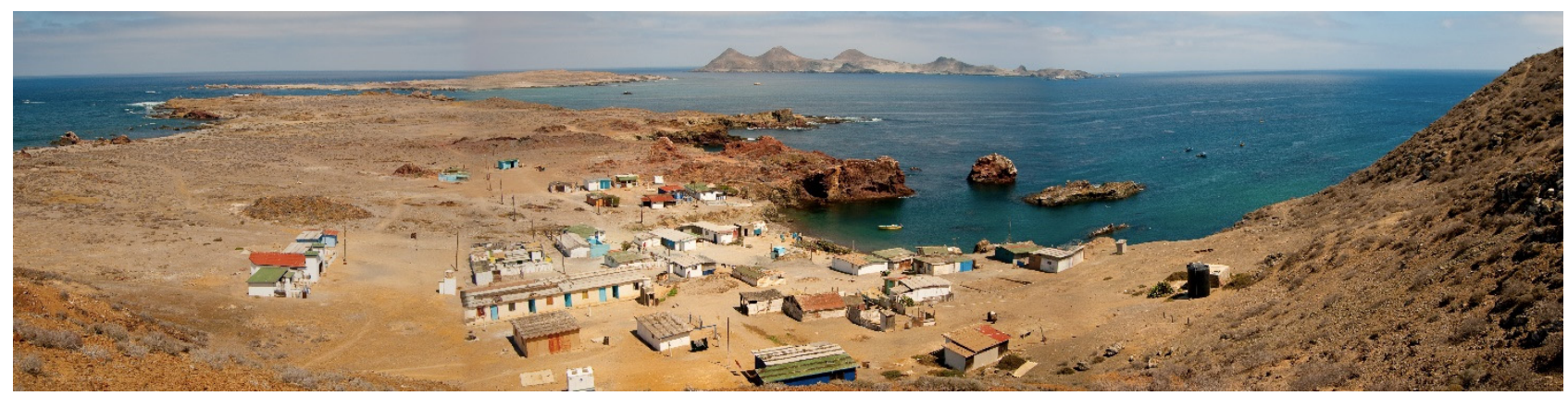

Figure 2. Panoramic view of Pescadores Nacionales de Abulón fishing camp on San Benito Oeste Island. This was the base of operations for the mouse eradication project. Photo: () GECI/J.A. Soriano.

\subsection{Rodent Detection and Monitoring}

Mice were first detected and reported by PNA in December 2006. There were sightings by fishermen on SBO who had reported it to PNA's members without any proof; the confirmation came with a photo of a dead individual caught on a trap. In August 2007, GECI conducted a survey to identify the species and to map its dispersion, as we knew the point of introduction was the township. We used live traps (H. Sherman, Tallahassee, FL, USA) for three consecutive nights and chew-blocks (made of a mixture of oats, peanut butter, and wax), as well as direct searches for signs of rodents at different locations across SBO. Live trapping for three consecutive nights was also performed on SBE and SBM.

Once the rodent species was identified through its morphological features and confirmed to occur only on SBO, we conducted further monitoring to collect ecological information on its population to inform the eradication plan. Live trapping was conducted systematically on SBO two or three times per year from 2008 to 2013. To estimate the mouse population density, a grid of 100 Sherman traps was installed at the top of the island: $10 \times 10$ traps separated by $10 \mathrm{~m}$ and baited with oat flakes. The mark-recapture method was applied with individual marking (metallic numbered ear tags) for five consecutive nights (Figure 3). The modified Schnabel method [41] was used to estimate the population density. The home range was estimated by fitting radio-collars on adult mice. The tracking was conducted at different hours of the day and night. The home range estimations were based on the minimum convex polygon method [42].

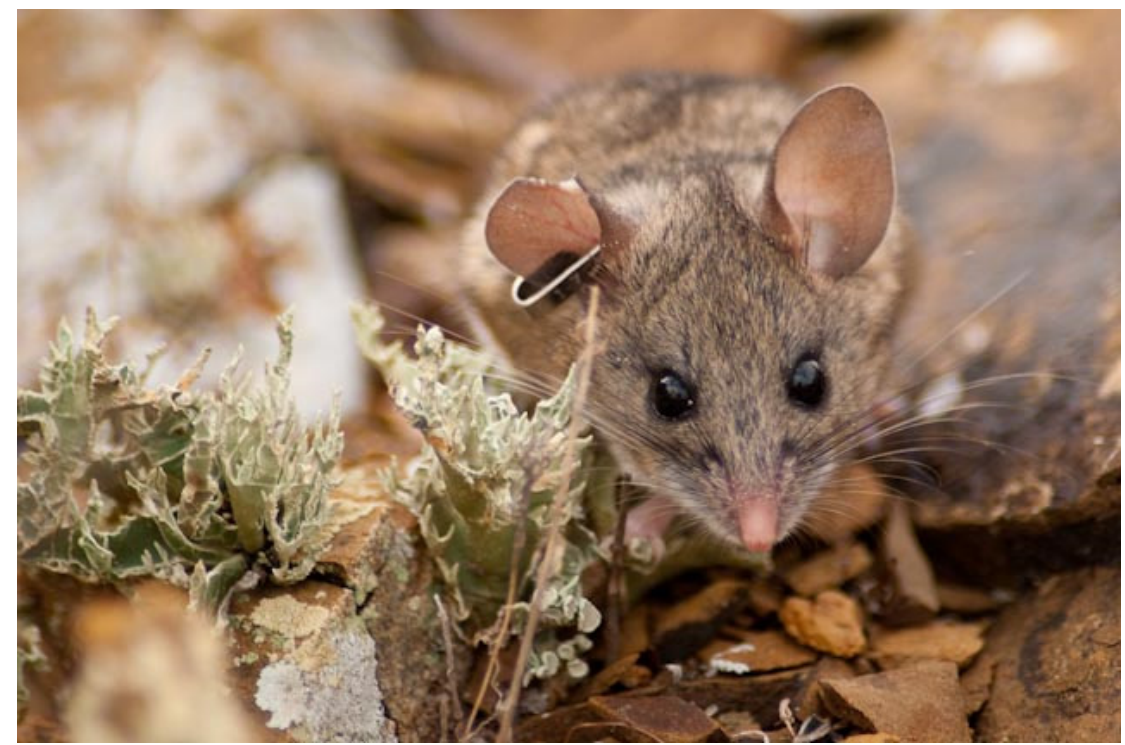

Figure 3. Cedros island cactus mouse (Peromyscus eremicus cedrosensis) invaded San Benito Oeste island in December 2006. Photo: @ GECI/J.A. Soriano. 


\subsection{Eradication Planning}

The feasibility planning was done by GECI in collaboration with PNA and the Mexican government [43]. GECI managed all the scientific and technical aspects of the project, while PNA committed to communicate its management board's approval of the project to all of its members and staff to ensure community support. Besides their genuine interest in the island's biodiversity, particularly its seabirds, PNA's Management Board also raised the concern about the mouse invasion becoming a public health issue for SBO inhabitants and thus wanted to implement control to lower this risk while the eradication occurred. Informal talks and semi-structured interviews [44] were held with members of the management board and with fishermen on SBO to assess the impacts of mice on their livelihoods.

The logistical support of PNA was essential during the project since they provided boat transport to and from SBO for every expedition, as well as housing on both Cedros and SBO islands. This in-kind support was provided as a commitment made by PNA, who also assumed tacit responsibility. PNA also performed an in-depth cleaning of their fishing camp on SBO before the eradication, which included the dismantling of several old houses and the collection and transport of these materials plus scrap, old unused wood and metal, and general waste, to Cedros.

\subsection{Implementation}

The selected method for the eradication was aerial baiting from a helicopter, with the operation following standard operating procedures [45] that had been previously conducted on other Mexican islands [19,20]. The bait used was the dry version of the rodenticide CI-25 (brodifacoum; Bell Laboratories Inc., Madison, WI, USA), specifically developed for ecological restoration purposes. The bait was delivered from a helicopter (Bell 206 Jet Ranger, Aspen Helicopters, Inc., Oxnard, CA, USA) equipped with a differential global positioning system (TracMap, Mosgiel, New Zealand) to ensure an accurate baiting and a DataLogger (TracMap, Mosgiel, New Zealand) to acquire detailed information about each baiting session to estimate bait density. A sowing bucket (Helicopters Otago, Ltd., Mosgiel, New Zealand) was used to spread the bait. To assess the aerial baiting and confirm bait distribution and application rates, we used a geographical information system procedure and developed the mathematical model we named as NERD: Numerical Estimation of Rodenticide Dispersal [46]. Two aerial baiting applications were conducted 7 days apart in November and December 2013, followed by a thorough hand baiting along the shore of the island. To avoid non-target impacts, particularly on birds, the eradication campaign was undertaken during the low breeding season. Attending to PNA's concerns of potential contamination with rodenticide, the helicopter avoided flying over human settlements for safety reasons. This meant that baiting within PNA's fishing camp was performed by hand and by setting up bait stations filled with bait blocks inside and underneath all the constructions.

Following a precautionary approach, an on-site aviary was installed and maintained to protect the savannah sparrow (Passerculus sandwichensis sanctorum) - an endemic species of the archipelago-since pre-eradication experiments demonstrated it consumed inert bait. To assess whether birds traveled between the three islands, and they belonged to the same population, we conducted two experiments, one consisting of banding birds with different color bands for each island and another consisting of a genetic analysis of feathers. Mist-nets and funnel traps were used to capture sparrows. Each captured bird was tagged with a numbered aluminum band and banded with a plastic color band: blue, green and black for SBO, SBM and SBE, respectively. Two tail feathers (rectrices number 6) and three breast feathers were collected for genetic tests. Feather samples were sent to EcoGene $^{\circledR}$ (www.ecogene.co.nz, accessed on 20 October 2021) for testing. 


\subsection{Confirmation}

To confirm the eradication's success, we used a statistical model known as Rapid Eradication Assessment (REA) [47], which consisted of a $150 \times 150 \mathrm{~m}$ grid of 160 chew-blocks throughout the island that was checked monthly after the eradication, up to November 2014. As an additional measure to confirm success, we continued rodent monitoring on SBO for two years after the mouse eradication.

\subsection{Wider Surveillance and Biosecurity}

Over the years, and on different occasions, we deployed Tomahawk live traps (Hazelhurst, WI, USA) in the fishing camp and its surroundings to record the presence/absence of rats. We continued monitoring SBE and SBM, mostly with chew-blocks and not systematically, to confirm that these islands remained rodent-free. PNA, including all of its members and employees, also committed to enforce the island's biosecurity in preparation for the eradication to avoid future rodent introductions, with a particular emphasis on the black rats that were present on Cedros.

On SBO, immediately after the eradication, we installed a total of 12 detection devices, called "rodent motels", comprising three different devices: tracking cards, chew-blocks, and snap-traps, for both mice and rats. The devices were set particularly around the boat-landing area near the fishing camp and along the east coast of the island, in the peninsula that is closer to SBM. The aim of these devices is to detect, and even stop, the incursion of rodents. The devices were checked for signs of rodent activity regularly by the fishermen living on SBO, and every time we visited the island, we conducted a check-up and maintenance.

\section{Results}

\subsection{Pre-Eradication Monitoring}

The total trapping effort was 119 trap-nights on SBO and 30 trap-nights on SBM and SBE. Captures or signs of rodents were only found on SBO, where the trapping success was $58.8 \%$. The only species caught was the cactus mouse, and it was widespread across the island (Figure 3). We recorded mice using seabird burrows, which alerted to a potential threat either by predation or competition, particularly because all of the nine breeding seabird species on SBO except the western gull (Larus occidentalis) are burrow-nesters [6]. In September 2008, we conducted another expedition to the SBA. Once again, we confirmed that SBM and SBE remained rodent-free. On SBO, after an effort of 210 trap-nights we had a 47\% trapping success, similar to that recorded in August 2007. By March 2009 (spring), we estimated a mouse density of 101.1 mice ha $^{-1}$ while in September (autumn) it was 58.7 mice ha $^{-1}$; home range varied from 142 to $2973 \mathrm{~m}^{2}$ [48].

\subsection{Eradication Planning and Implementation}

Interviews and informal talks with fishermen on $\mathrm{SBO}$ revealed that the mouse population was not only a threat to native flora and fauna but was also a concern for public health [48]. Mice were continuously getting into the houses, negatively affecting the livelihoods of fishermen and their families. An additional concern was over the known capacity of rodents to carry zoonotic diseases and transmit them to humans [49]. Because of these negative impacts, fishermen started using a second-generation anticoagulant called Difenacoum (Sorexa ${ }^{\circledR}$ Blocks, BASF The Chemical Company, Mexico City, Mexico) to control mice in their households. To avoid mice becoming resistant to this kind of rodenticide and thereby jeopardize the forthcoming eradication, which involved the use of Brodifacoum - also a second-generation anticoagulant-GECI staff asked PNA to stop using chemical control on SBO and proposed the use of lethal traps (e.g., Victor ${ }^{\circledR}$ Easy Set $^{\circledR}$ Mouse Trap, Woodstream Corporation, Inc., Lancaster, PA, USA) as the preferred option, or first-generation anticoagulants.

Baseline monitoring to inform the eradication plan started in 2008. In 2009, PNA provided its approval and support to the project and formally committed to provide in- 
kind support and participate in different activities, particularly biosecurity. Between 2010 and 2012, GECI conducted the pre-eradication monitoring, formulated the operational plan, conducted the necessary logistics, and developed and implemented island biosecurity; these last two activities were performed in coordination with PNA (Table 1). Funding for the mouse eradication on SBO was secured by GECI in 2012. The total cost was US \$ $659,056.15$ (Table 2), excluding pre- and post-eradication activities. The first and second aerial baiting took place on 27 November and 4 December 2013, respectively, one week apart as planned (Figure 4). The median application rate estimated with NERD [46] after the two bait drops was $8.6 \mathrm{~kg} \mathrm{ha}^{-1}$. A total of $25-30$ people participated in the whole operation, with overall coordination by experienced personnel from GECI.

Table 1. PNA's involvement at the different stages of the mouse eradication on San Benito Oeste Island.

\begin{tabular}{ccc}
\hline Phase of Project & PNA Input & Technical Input \\
\hline Detection of mice & Passive surveillance & PNA \\
Species identification & Transport and housing & GECI \\
Ecology of mice & Transport and housing & GECI \\
Feasibility and planning & PNA management board & GECI \\
Logistics & Transport and housing & GECI, SEMAR \\
Funding & In-kind support & GECI and external \\
Eradication & Ground baiting & GECI \\
Non-target mitigation & Transport and housing & GECI \\
Validation of absence & Transport and housing & GECI \\
Biosecurity & Active surveillance & GECI, CONANP \\
\hline
\end{tabular}

Table 2. Cost estimates of the mouse eradication on San Benito Oeste Island.

\begin{tabular}{cc}
\hline Item & Cost (USD) \\
\hline Preparation and planning & $55,615.07$ \\
Helicopter & $56,529.90$ \\
Aerial bucket & 1 \\
Bait & $3191.30^{2}$ \\
Boat expenses & $110,000.00^{3}$ \\
Staff & $194,067.71$ \\
Food, travel, fuel, materials & $165,403.15$ \\
Lodging and air and ground transportation & $36,202.58$ \\
Field equipment and materials & $38,046.44$ \\
\hline Total & $659,056.15$ \\
\hline
\end{tabular}

${ }^{1}$ The aerial bucket was already owned by GECI. ${ }^{2} \mathrm{~A}$ total of $8000 \mathrm{~kg}$ of bait was donated by Bell Laboratories Inc. The cost shown is for the shipment and importation from USA to Mexico. ${ }^{3}$ In-kind support from the Mexican Navy that provided the long-range oceanic patrol vessel ARM Bretón, and from the fishing cooperative Pescadores Nacionales de Abulón, which provided continuous trips from the Baja California Peninsula (Punta Eugenia) to Cedros island and then to San Benito Oeste.

We found that the San Benito Savannah Sparrow travels among the islands [48,50]. We also confirmed that all the birds of the three islands belong to the same population. Genetic tests confirmed similar levels of genetic diversity across all three island populations; there was low differentiation between SBM and both SBE and SBO, while there was moderate differentiation between SBE and SBO populations. This suggests that high gene flow is occurring via migration between SBM and neighboring SBE and SBO, with slightly less gene flow between SBE and SBO. The overall migration rate, as estimated through allele frequency comparisons, was an average of 6.43 breeding individuals being exchanged between populations/generation [51]. Despite these findings, as a precautionary measure, 47 birds were kept in captivity during the eradication and while the bait was still available on the ground (from November 2013 until June 2014). Eleven birds, all females, died on 28 December 2013. The cause of death was not consumption of bait but rather environmental conditions: low temperatures and cold winds. Measures such as insulation with tarps and added foliage to 
the nests were taken to improve conditions for the birds in the aviary and no further deaths were recorded. The remaining 36 birds were released in June 2014, 11 of which were fitted with bands and radio-telemetry transmitters to assess acclimatization and movements. All the birds survived post-release. By 2016, three years after the eradication, SBE had the highest average density (2009-2016) of this species (33.25 ind. ha ${ }^{-1} \pm 42.19 \mathrm{SE}$ ), followed by SBM (19.51 ind. ha $\left.{ }^{-1} \pm 3.86 \mathrm{SE}\right)$, and SBO (6.08 ind. ha $\left.{ }^{-1} \pm 5.59 \mathrm{SE}\right)$. The population in SBO remained stable and was not affected by the mouse eradication [50].

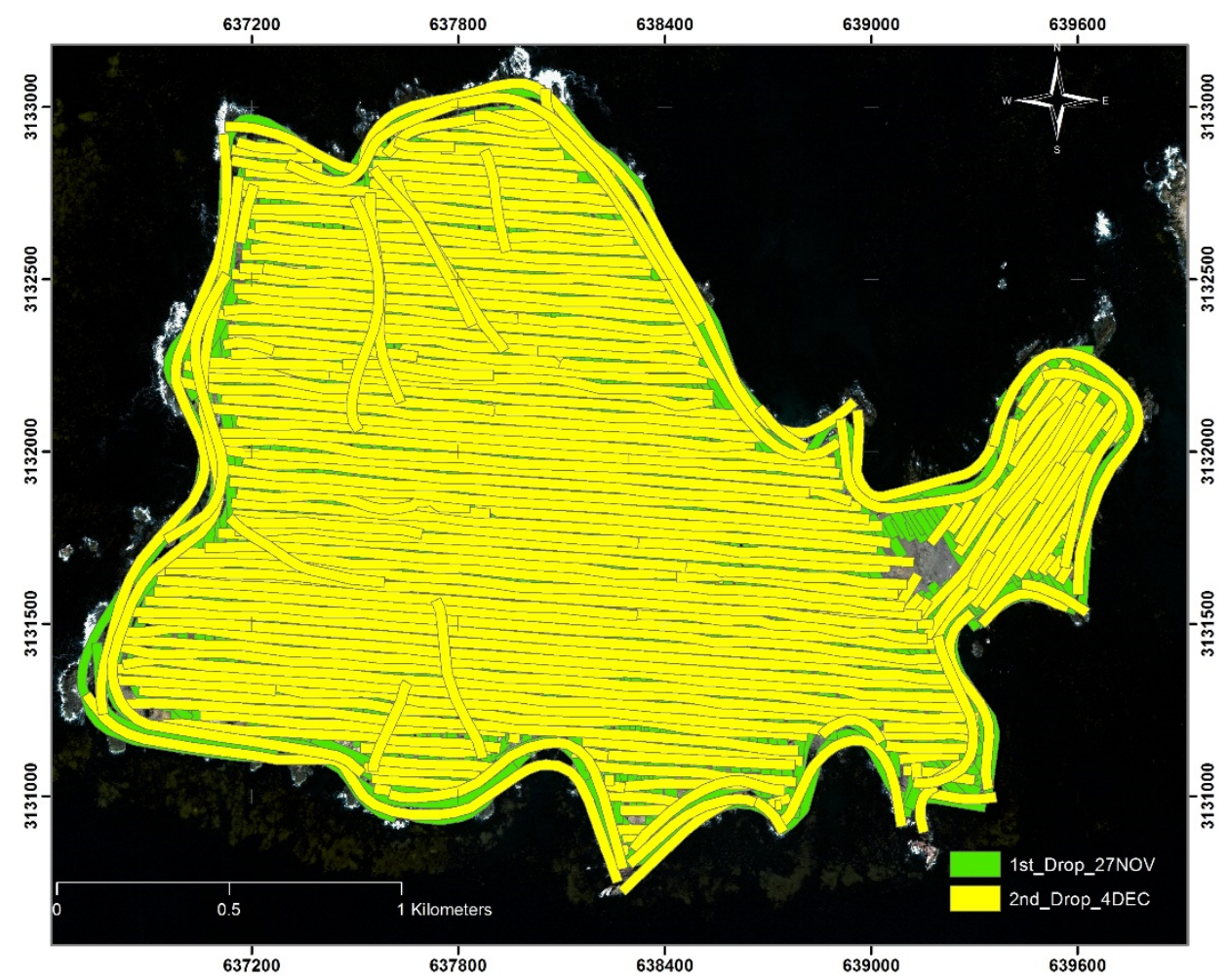

Figure 4. Map showing the helicopter coverage during the first (green; 27 November 2013) and second (yellow; 4 December 2013) bait drops during the mouse eradication on San Benito Oeste island. The gap shown to the east is where the fishing camp is located, which was treated by hand and bait stations after each bait drop.

A 30 min documentary was produced to tell the story of the island's seabirds and restoration project; the film, called "San Benito Archipelago: A Symphony for the Seabirds" in Spanish and featuring English subtitles, is publicly available: https:/ / youtu.be/4Kv5 np70ETs (accessed on 26 October 2021).

\subsection{Confirmation}

The REA indicated a high probability of success (93-99\%) one month after completing the second bait application. We complemented the latter with systematic post-eradication monitoring during 2014 and 2015, confirming that SBO was rodent-free and thus the success of the eradication. The other two islands remained uninvaded. To date, the SBA is free of invasive mammals.

\subsection{Wider Surveillance and Biosecurity}

Using intuition and with no formal implementation, fishermen on SBO enforced the early detection phase of island biosecurity when they detected and reported the mouse invasion in late-2006. They were aware of the importance of keeping these islands pestfree from previous restoration projects conducted there and from the somewhat frequent exchange with GECI's personnel, who were conducting a restoration project on Cedros Island to control feral dogs at the time. At the same time, PNA and GECI, along with 
FEDECOOP and other affiliated fishing cooperatives, were already working together to convince the federal government to designate these islands as a protected area [22]. Ever since, biosecurity and a conservation culture has been shaped for the Cedros-San Benito island complex and the region as a whole [52-54]. To develop a formal biosecurity program, the first step was creating awareness, so we conducted community workshops and talks with fishermen on SBO and Cedros. We complemented this comprehensive approach with outreach materials such as brochures, posters, and offset printed blankets, followed by detailed biosecurity measures, to prevent accidental introductions. Since 2013, we have held biosecurity workshops with the fishermen in $\mathrm{SBO}$ and Cedros with the goal of involving all PNA members and staff working on the SBA. Furthermore, to ensure that every person that visits SBO learns about biosecurity, since 2017 we have held Environmental Fairs in Cedros Island, with activities regarding environmental education for children and adults, spanning from music workshops, mural painting, photography and film exhibitions, and sculpture contests. Each year, approximately 200 people participate in the fairs [55].

PNA's knowledge of island biosecurity was also derived from the participation of two of its members in the first of its kind in Mexico: "Workshop on island biosecurity for managers, park rangers and users of natural protected areas", in March 2014, co-organized by the National Commission for the Knowledge and Use of Biodiversity (CONABIO), US Fish and Wildlife Service, Pacific Invasives Initiative, and GECI. This was part of the activities of a Global Environment Facility (GEF)-funded project "Enhancing National Capacities to Manage Invasive Alien Species (IAS) by Implementing the National Strategy on Invasive Species", executed by the United Nations Development Program (UNDP) in Mexico, CONABIO and CONANP [56]. As an outcome of this workshop, a first island biosecurity protocol for the Cedros-San Benito island complex was drafted [52]. This island biosecurity protocol has been updated, reviewed, and adapted over the years, with its formal implementation and enforcement by CONANP since 2017 after the creation of the Baja California Pacific Islands Biosphere Reserve. In 2019, in a meeting with CONANP, PNA and GECI staff, we reviewed the biosecurity protocol and updated it. Furthermore, we had a special workshop in Cedros and SBO to build capacities for CONANP's park rangers and PNA staff.

\section{Discussion}

A key to the success of this project has been the long-lasting collaboration between GECI and the fishing cooperatives on the Baja California Pacific Islands, and between GECI and the Mexican Navy and other federal government agencies. This project is the first and only eradication to date of a Peromyscus in the world [12,57], the first mouse eradication using aerial baiting in Mexico [20], as well as the largest island in the country from which mice have been successfully removed $[10,11]$. It is also a project that stands out from other eradications conducted in Mexico since, in the case of SBO, the local community was involved and committed throughout the project. PNA recognized and took responsibility for the accidental introduction of the Cedros island cactus mouse to SBO and made every effort to be involved and implement a permanent solution with GECI. This commitment reveals how this fishing cooperative, like the other cooperatives in the region, are environmental stewards of the islands they live in an depend upon. These local fishing communities not only practice sustainable management of their fisheries but they also care for and embrace a hands-on approach for island conservation and restoration [37]. PNA's island condition provides the cooperative with strong incentives to protect not only the marine resources it depends on but also the ecosystem it inhabits, because it is aware that any impact on the terrestrial ecosystem could impact the marine ecosystem, as recent research has revealed [58-60]. In this sense, the cooperative has become a strong steward of Cedros island and the San Benito Archipelago. Similar involvement of island communities has been documented in other countries, such as Chile [61], New Zealand [62], and Australia [14]. 
The strong support from the local fishing community was an enabling condition to secure funding since it made clear that they would not raise any concerns nor opposition. Such support was also relevant during the acquisition of permits and to obtain logistical support from the Mexican Navy. Overall, this project was a success because of the partners involved: a well-organized and mature fishing community (PNA), a consolidated and experienced civil society organization (GECI), and a strong network of federal government agencies. Trust among the partners was essential. For instance, PNA and GECI had already been collaborating for almost 15 years, and personal relationships between members of the two organizations have been unfolding for more than 40 years. Similarly, GECI had been working closely for several years with government agencies such as the ministries of Interior (SEGOB), Navy (SEMAR) and Environment (SEMARNAT) to restore island ecosystems in Mexico and to develop public policies on island conservation [21,63]. If PNA had not backed the project as it did, it might have taken more time to develop. Since the whole island is federal property, the decision might have been made by the federal government as a must-do action despite PNA's opposition or indifference. However, the cost-effectiveness of such a project might have been jeopardized, since there would have been no commitment from the local community to enforce biosecurity, making the risk of reintroduction very high. Opposition by local communities has already halted eradication projects on many islands, such as Lord Howe Island and Great Barrier Island [15]. Therefore, PNA's support and involvement made the eradication project on SBO very straightforward and with no additional challenges other than those intrinsic to these types of operations.

Eight years since the mouse eradication on $\mathrm{SBO}$, no rodents have been recorded, despite these species occurring on the nearby Cedros island. PNA continues with its regular fishing activities, which involves practically moving households from Cedros to SBO during abalone and lobster seasons every year. This suggests that the island biosecurity practiced by PNA and enforced by CONANP, with technical assistance from GECI, is working, as well as indicating that fishermen are more aware about the implications of living with rodents, thus making it an intrinsic incentive to implement island biosecurity measures. Such behavior and rationale have been observed on other inhabited Mexican islands where invasive rodents have been eradicated [52,53,64].

Although the SBO mouse eradication cannot be viewed as a rapid response since the introduction occurred in 2006 and the eradication took place in 2013, from a precautionary approach perspective for the island ecosystem, the response was methodical and efficient. In seven years, the science behind the project was produced [43,48], funding was secured, and interinstitutional coordination took place to implement the eradication project. Seabirds where the group that benefited the most since the SBA archipelago is a major seabird site, especially because mice of the Peromyscus genus have been recognized as predators of terrestrial invertebrates and ground-nesting birds, and they can also prey on and compete with burrow-nesting seabirds such as storm-petrels and alcids [65,66]. Thanks to these collective and interinstitutional efforts, the most important seabird islands in the Mexican Pacific remain a safe haven for seabirds. Additionally, the restoration work conducted under such a close partnership between one of the most prominent fishermen cooperatives in the country, government agencies, and GECI — as a social construction [67] also contributed to building the trust and culture that gave birth to the Baja California Pacific Islands Biosphere Reserve [22], a highly significant outcome.

Author Contributions: Conceptualization, F.M.S., A.A.-M. and A.S.; methodology, F.M.S., A.A.-M., A.S., Y.B.G., E.R.M.; software, F.M.S., A.C.T., E.R.M.; validation, A.A.-M., A.S., P.K., A.C.V., G.A.F., L.F.B.M. and A.O.-R.; formal analysis, F.M.S., A.A.-M., Y.B.G., A.C.T., E.R.M.; investigation, F.M.S., A.S., Y.B.G., M.L.R.; resources, F.M.S. and A.A.-M.; data curation, A.S., Y.B.G., A.C.T., E.R.M. and M.L.R.; writing—original draft preparation, F.M.S.; writing—review and editing, F.M.S., A.A.-M., A.S., Y.B.G., A.C.T., E.R.M., M.L.R., P.K., A.C.V., G.A.F., L.F.B.M. and A.O.-R.; visualization, F.M.S., A.C.T. and E.R.M.; supervision, F.M.S., A.A.-M., P.K., A.C.V., G.A.F., L.F.B.M. and A.O.-R.; project administration, F.M.S. and A.A.-M.; funding acquisition, F.M.S. and A.A.-M. All authors have read and agreed to the published version of the manuscript. 
Funding: This research was funded by the National Fish and Wildlife Foundation, the David and Lucile Packard Foundation, Marisla Foundation, the Global Environment Facility, and the United Nations Development Program.

Institutional Review Board Statement: This project was conducted under the following permits from the General Directorate of Wildlife (Dirección General de Vida Silvestre) of Mexico's Ministry of Environment and Natural Resources (Secretaría de Medio Ambiente y Recursos Naturales, SEMARNAT): SGPA/DGVS/10829/12 for the eradication using aerial bating of the CI-25 rodenticide; SGPA/DGVS/12202/13 for the collection, captivity, marking with metallic bands and fitting with transmitters of up to 100 individuals of the savannah sparrow. The Ministry of the Interior (SEGOB) granted permits to visit federal insular territory and temporarily install an aviary for savannah sparrows: DICOPPU/211/2483/13 and DICOPPU/211/81/10. Permits for the import from the USA and use of the rodenticide were granted by the General Directorate for the Comprehensive Management of Materials and Risk Activities (Dirección General de Gestión Integral de Materiales y Actividades Riesgosas) of SEMARNAT: DGGIMAR.710006890; the Federal Commission for the Protection Against Sanitary Risks (COFEPRIS) of the Ministry of Health: 133300121J0007; and the Tax Administration Service: 900-03-05-2013-74038.

Informed Consent Statement: Informed consent was obtained from all subjects involved in the study.

Data Availability Statement: Please see within the paper.

Acknowledgments: The Navy Ministry (SEMAR) facilitated the operational logistics by transporting bait, fuel, water, equipment and personnel from Ensenada to San Benito Oeste onboard the long-range oceanic patrol vessel ARM Bretón, with a hangar and helicopter platform. The National Commission of Natural Protected Areas (CONANP), as well as the ministries of Interior (SEGOB), Environment and Natural Resources (SEMARNAT), Communications and Transport (SCT) and National Defense (SEDENA) supported the project and facilitated the required permits. We thank Bell Laboratories, Inc. for the bait donation, TracMap and Heliotago for their advice on DGPS and DataLogger usage, and Aspen Helicopters for their commitment and precise work during the aerial baiting. We thank the Red Temática de Investigación en Áreas Naturales Protegidas (RENANP) of the Consejo Nacional de Ciencia y Tecnología (CONACyT), the CONACyT Basic Science project 251919, and the Centro de Investigaciones Biológicas del Noroeste (CIBNOR). We thank Marlenne Rodríguez Malagón, Karina Ramos Rendón and many other professionals for participating in pre-eradication monitoring. Our greatest gratitude goes to PNA's management boards-past and present-and all its members for letting us work alongside with them to protect, conserve, and restore the amazing islands they call home.

Conflicts of Interest: The authors declare no conflict of interest. The funders had no role in the design of the study; in the collection, analyses, or interpretation of data; in the writing of the manuscript, or in the decision to publish the results.

\section{References}

1. Mulder, C.P.H.; Anderson, W.B.; Towns, D.R.; Bellingham, P.J. (Eds.) Seabird Islands: Ecology, Invasion, and Restoration; Oxford University Press: New York, NY, USA, 2011.

2. Provencher, J.F.; Borrelle, S.; Sherley, R.B.; Avery-Gomm, S.; Hodum, P.; Bond, A.; Major, H.L.; McCoy, K.D.; Crawford, R.; Merkel, F.; et al. Seabirds. In World Seas: An Environmental Evaluation, 2nd ed.; Sheppard, C., Ed.; Academic Press: New York, NY, USA, 2019; pp. 133-162.

3. Spatz, D.R.; Newton, K.M.; Heinz, R.; Tershy, B.; Holmes, N.D.; Butchart, S.H.M.; Croll, D.A. The Biogeography of Globally Threatened Seabirds and Island Conservation Opportunities. Conserv. Biol. 2014, 28, 1282-1290. [CrossRef]

4. Croxall, J.P.; Butchart, S.H.M.; Lascelles, B.; Stattersfield, A.J.; Sullivan, B.; Symes, A.; Taylor, P. Seabird conservation status, threats and priority actions: A global assessment. Bird Conserv. Int. 2012, 22, 1-34. [CrossRef]

5. Dias, M.P.; Martin, R.; Pearmain, E.J.; Burfield, I.J.; Small, C.; Phillips, R.A.; Yates, O.; Lascelles, B.; Borboroglu, P.G.; Croxall, J.P. Threats to seabirds: A global assessment. Biol. Conserv. 2019, 237, 525-537. [CrossRef]

6. Méndez Sánchez, F.; Bedolla Guzmán, Y.; Rojas Mayoral, E.; Aguirre-Muñoz, A.; Koleff, P.; Aguilar Vargas, A.; Álvarez Santana, F.; Arnaud, G.; Aztorga Ornelas, A.; Beltrán Morales, L.F.; et al. Population ecology of seabirds in Mexican Islands at the California Current System. bioRxiv 2021. [CrossRef]

7. Wolf, S.; Keitt, B.; Aguirre-Muñoz, A.; Tershy, B.; Palacios, E.; Croll, D. Transboundary seabird conservation in an important North American marine ecoregion. Environ. Conserv. 2006, 33, 294-305. [CrossRef]

8. Doherty, T.S.; Glen, A.S.; Nimmo, D.G.; Ritchie, E.G.; Dickman, C.R. Invasive predators and global biodiversity loss. Proc. Natl. Acad. Sci. USA 2016, 113, 11261-11265. [CrossRef] 
9. Bellard, C.; Cassey, P.; Blackburn, T.M. Alien species as a driver of recent extinctions. Biol. Lett. 2016, 12, 20150623. [CrossRef] [PubMed]

10. Aguirre-Muñoz, A.; Bedolla-Guzmán, Y.; Hernández-Montoya, J.; Latofski-Robles, M.; Luna-Mendoza, L.; Méndez-Sánchez, F.; Ortiz-Alcaraz, A.; Rojas-Mayoral, E.; Samaniego-Herrera, A. The Conservation and Restoration of the Mexican Islands, a Successful Comprehensive and Collaborative Approach Relevant for Global Biodiversity. In Mexican Natural Resources Management and Biodiversity Conservation: Recent Case Studies; Ortega-Rubio, A., Ed.; Springer International Publishing: Cham, Switzerland, 2018; pp. 177-192.

11. Aguirre-Muñoz, A.; Samaniego-Herrera, A.; Luna-Mendoza, L.; Ortiz-Alcaraz, A.; Rodríguez-Malagón, M.; Méndez-Sánchez, F.; Félix-Lizárraga, M.; Hernández-Montoya, J.C.; González-Gómez, R.; Torres-García, F.; et al. Island restoration in Mexico: Ecological outcomes after systematic eradications of invasive mammals. In Island Invasives: Eradication and Management, Proceedings of the International Conference on Island Invasives, Auckland, New Zealand, 8-12 February 2010; Veitch, C.R., Clout, M.N., Towns, D.R., Eds.; Occasional Paper of the IUCN Species Survival Commission No. 42; IUCN: Gland, Switzerland; CBB: Auckland, New Zealand, 2011; pp. 250-258.

12. Howald, G.; Donlan, C.J.; Galván, J.P.; Russell, J.C.; Parkes, J.; Samaniego, A.; Wang, Y.; Veitch, D.; Genovesi, P.; Pascal, M.; et al. Invasive Rodent Eradication on Islands. Conserv. Biol. 2007, 21, 1258-1268. [CrossRef] [PubMed]

13. Towns, D.R.; Broome, K.G. From small Maria to massive Campbell: Forty years of rat eradications from New Zealand islands. N. Z. J. Zool. 2003, 30, 377-398. [CrossRef]

14. Harper, G.A.; Pahor, S.; Birch, D. The Lord Howe Island Rodent Eradication: Lessons Learnt from an Inhabited Island. In Proceedings of the 29th Vertebrate Pest Conference, Santa Barbara, CA, USA, 2-5 March 2020; p. 11.

15. Glen, A.S.; Atkinson, R.; Campbell, K.J.; Hagen, E.; Holmes, N.D.; Keitt, B.S.; Parkes, J.P.; Saunders, A.; Sawyer, J.; Torres, H. Eradicating multiple invasive species on inhabited islands: The next big step in island restoration? Biol. Invasions 2013, 15, 2589-2603. [CrossRef]

16. Brooke, M.d.L.; Bonnaud, E.; Dilley, B.J.; Flint, E.N.; Holmes, N.D.; Jones, H.P.; Provost, P.; Rocamora, G.; Ryan, P.G.; Surman, C.; et al. Seabird population changes following mammal eradications on islands. Anim. Conserv. 2018, 21, 3-12. [CrossRef]

17. Holmes, N.D.; Spatz, D.R.; Oppel, S.; Tershy, B.; Croll, D.A.; Keitt, B.; Genovesi, P.; Burfield, I.J.; Will, D.J.; Bond, A.L.; et al. Globally important islands where eradicating invasive mammals will benefit highly threatened vertebrates. PLoS ONE 2019, 14, e0212128. [CrossRef] [PubMed]

18. Barbraud, C.; Delord, K.; Le Bouard, F.; Harivel, R.; Demay, J.; Chaigne, A.; Micol, T. Seabird population changes following mammal eradication at oceanic Saint-Paul Island, Indian Ocean. J. Nat. Conserv. 2021, 63, 126049. [CrossRef]

19. Samaniego-Herrera, A.; Aguirre-Muñoz, A.; Bedolla-Guzmán, Y.; Cárdenas-Tapia, A.; Félix-Lizárraga, M.; Méndez-Sánchez, F.; Reina-Ponce, O.; Rojas-Mayoral, E.; Torres-García, F. Eradicating invasive rodents from wet and dry tropical islands in Mexico. Oryx 2017, 52, 559-570. [CrossRef]

20. Samaniego-Herrera, A.; Aguirre-Muñoz, A.; Rodríguez-Malagón, M.; González-Gómez, R.; Torres-García, F.; Méndez-Sánchez, F.; Félix-Lizárraga, M.; Latofski-Robles, M. Rodent eradications on Mexican islands: Advances and challenges. In Island Invasives: Eradication and Management, Proceedings of the International Conference on Island Invasives, Auckland, New Zealand, 8-12 February 2010; Veitch, C.R., Clout, M.N., Towns, D.R., Eds.; Occasional Paper of the IUCN Species Survival Commission No. 42; IUCN: Gland, Switzerland; CBB: Auckland, New Zealand, 2011; pp. 350-355.

21. Aguirre-Muñoz, A.; Samaniego-Herrera, A.; Luna-Mendoza, L.; Ortiz-Alcaraz, A.; Rodríguez-Malagón, M.; Félix-Lizárraga, M.; Méndez-Sánchez, F.; González-Gómez, R.; Torres-García, F.; Hernández-Montoya, J.C.; et al. Eradications of invasive mammals on islands in Mexico: The roles of history and the collaboration between government agencies, local communities and a non-government organisation. In Island Invasives: Eradication and Management, Proceedings of the International Conference on Island Invasives, Auckland, New Zealand, 8-12 February 2010; Veitch, C.R., Clout, M.N., Towns, D.R., Eds.; Occasional Paper of the IUCN Species Survival Commission No. 42; IUCN: Gland, Switzerland; CBB: Auckland, New Zealand, 2011; pp. $386-394$.

22. Aguirre-Muñoz, A.; Méndez-Sánchez, F. The New Baja California Pacific Islands Biosphere Reserve Sets a Conservation Benchmark: All Mexican Islands are Now Protected. FREMONTIA J. Calif. Native Plant Soc. 2017, 42, 27-31.

23. Donlan, C.J.; Tershy, B.R.; Croll, D.A. Islands and Introduced Herbivores: Conservation Action as Ecosystem Experimentation. J. Appl. Ecol. 2002, 39, 235-246. [CrossRef]

24. Sydeman, W.; Elliott, M. Developing the California Current Integrated Ecosystem Assessment, Module I: Select Time-Series of Ecosystem State. 2008. Available online: https://static1.squarespace.com/static/56a6b01dd8af105db2511b83/t/5760509d2eeb8 13699c0f046/1465929889374/IEA+Step+1+Rpt+Final.pdf (accessed on 25 October 2021).

25. McClatchie, S. Regional Fisheries Oceanography of the California Current System: The CalCOFI Program; Springer: Dordrecht, The Netherlands, 2014.

26. DOF. DECRETO por el que se declara Área Natural Protegida, con el Carácter de Reserva de la Biosfera, la Región Conocida como Islas del Pacífico de la Península de Baja California. 2016. Available online: https:/ /www.dof.gob.mx/nota_detalle.php? codigo $=5464451 \&$ fecha $=07 / 12 / 2016$ (accessed on 20 October 2021).

27. Junak, S.A.; Philbrick, R. Flowering plants of the San Benito Islands, Baja California, Mexico. In Proceedings of the Fifth California Islands Symposium, Santa Barbara, CA, USA, 29 March-1 April 1999; Browne, D.H., Chaney, H., Mitchell, K., Eds.; Santa Barbara Museum of Natural History: Santa Barbara, CA, USA, 2000; pp. 235-246. 
28. Heckel, G.; Ruiz Mar, G.; Schramm, Y.; Gorter, U. Atlas de Distribución y Abundancia de Mamíferos Marinos en México; Universidad Autónoma de Campeche, Instituto de Ecología, Pesquerías y Oceanografía del Golfo de México (EPOMEX): Campeche, Mexico, 2020.

29. Samaniego Herrera, A.; Peralta García, A.; Aguirre Muñoz, A. (Eds.) Vertebrados de las Islas del Pacífico de Baja California: Guía de Campo; Grupo de Ecología y Conservación de Islas, A.C.: Ensenada, Mexico, 2007; p. 178.

30. Wolf, S.; Phillips, C.; Zepeda-Dominguez, J.A.; Albores-Barajas, Y.; Martin, P. Breeding biology of Xantus's Murrelet at the San Benito Islands, Baja California, México. Mar. Ornithol. 2005, 33, 123-129.

31. Bedolla-Guzmán, Y.; Masello, J.F.; Aguirre-Muñoz, A.; Lavaniegos, B.E.; Quillfeldt, P. Breeding biology, chick growth, and diet of the Least Storm-Petrel Oceanodroma microsoma on Islas San Benito, Mexico. Mar. Ornithol. 2017, 45, 129-138.

32. Whitworth, D.L.; Carter, H.R.; Palacios, E.; Gress, F. Breeding of Craveri's Murrelet Synthliboramphus craveri at four islands off west-central baja california, México. Mar. Ornithol. 2018, 46, 117-124.

33. Bedolla-Guzmán, Y.; Méndez-Sánchez, F.; Aguirre-Muñoz, A.; Félix-Lizárraga, M.; Fabila-Blanco, A.; Bravo-Hernández, E.; Hernández-Ríos, A.; Corrales-Sauceda, M.; Aguilar-Vargas, A.; Aztorga-Ornelas, A.; et al. Recovery and current status of seabirds on the Baja California Pacific Islands, Mexico, following restoration actions. In Island Invasives: Scaling up to Meet the Challenge; Veitch, C.R., Clout, M.N., Martin, A.R., Russell, J.C., West, C.J., Eds.; Occasional Paper SSC no. 62; IUCN: Gland, Switzerland, 2019; pp. 531-538.

34. Bedolla-Guzmán, Y.; Masello, J.F.; Aguirre-Muñoz, A.; Lavaniegos, B.E.; Voigt, C.C.; Gómez-Gutiérrez, J.; Sánchez-Velasco, L.; Robinson, C.J.; Quillfeldt, P. Year-round niche segregation of three sympatric Hydrobates storm-petrels from Baja California Peninsula, Mexico, Eastern Pacific. Mar. Ecol. Prog. Ser. 2021, 664, 207-225. [CrossRef]

35. Vidal, R.M.; Berlanga, H.; Del Coro Arizmendi, M. Important Bird Areas: Mexico. In Important Bird Areas Americas—Priority Sites for Biodiversity Conservation; BirdLife Conservation Series No. 16; BirdLife International: Quito, Ecuador, 2009.

36. Ponce-Díaz, G.; Weisman, W.; McCay, B.J. Co-Responsability and Participation in Fisheries Management in Mexico: Lessons from Baja California Sur. Pesca Y Conserv. 2009, 1, 1-9.

37. Méndez Sánchez, F.A. Co-Management and Small-Scale Fisheries in Mexico: The Case of a Fishers' Cooperative in Cedros and San Benito Islands; The University of Auckland: Auckland, New Zealand, 2012.

38. Phillips, B.; Bourillón, L.; Ramade, M. Case Study 2: The Baja California, Mexico, Lobster Fishery. In Seafood Ecolabelling: Principles and Practice; Ward, T., Phillips, B., Eds.; Blackwell Publishing Ltd.: Chichester, UK, 2008; pp. 259-268.

39. Álvarez, P.; Delgado, C.; Espejel, I.; Seingier, G. Historia Ambiental del comanejo adaptativo en dos regiones pesqueras del noroeste mexicano. Relac. Estud. De Hist. Y Soc. 2018, 39, 41. [CrossRef]

40. Mccay, B.J. Territorial Use Rights in Fisheries of the Northern Pacific Coast of Mexico. Bull. Marine Sci. 2017, 93, 69-81. [CrossRef]

41. Krebs, C.J. Mammals. In Ecological Census Techniques: A Handbook, 2nd ed.; Sutherland, W.J., Ed.; Cambridge University Press: Cambridge, UK, 2006; pp. 351-369.

42. Burgman, M.A.; Fox, J.C. Bias in species range estimates from minimum convex polygons: Implications for conservation and options for improved planning. Anim. Conserv. 2003, 6, 19-28. [CrossRef]

43. GECI. Propuesta de Erradicación del Ratón Introducido en la isla San Benito Oeste, México; GECI: Ensenada, Mexico, 2009 ; p. 42.

44. Bernard, H.R. Research Methods in Anthropology: Qualitative and Quantitative Approaches, 5th ed.; AltaMira Press: Lanham, MD, USA, 2011.

45. Broome, K.G.; Cox, A.; Golding, C.; Cromarty, P.; Bell, P.; McLelland, P. Rat Eradication Using Aerial Baiting: Current Agreed Best Practice Used in New Zealand (Version 3.0); New Zealand Department of Conservation: Wellington, New Zeland, 2014.

46. Rojas-Mayoral, E.; Méndez-Sánchez, F.; Rojas-Mayoral, B.; Aguirre-Muñoz, A. Improving the efficiency of aerial rodent eradications by means of the numerical estimation of rodenticide density. In Island Invasives: Scaling up to Meet the Challenge; Veitch, C.R., Clout, M.N., Martin, A.R., Russell, J.C., West, C.J., Eds.; Occasional Paper SSC no. 62; IUCN: Gland, Switzerland, 2019; pp. 47-50.

47. Samaniego-Herrera, A.; Anderson, D.P.; Parkes, J.P.; Aguirre-Muñoz, A. Rapid assessment of rat eradication after aerial baiting. J. Appl. Ecol. 2013, 50, 1415-1421. [CrossRef]

48. GECI. Introduced Mouse Eradication on San Benito Oeste Island, Mexico: 3rd Pre-Eradication Report; Grupo de Ecología y Conservación de Islas, A.C.: Ensenada, Mexico, 2010; p. 58.

49. de Wit, L.A.; Croll, D.A.; Tershy, B.; Newton, K.M.; Spatz, D.R.; Holmes, N.D.; Kilpatrick, A.M. Estimating Burdens of Neglected Tropical Zoonotic Diseases on Islands with Introduced Mammals. Am. J. Trop. Med. Hyg. 2017, 96, 749-757. [CrossRef]

50. Méndez-Sánchez, F.; Aguirre-Muñoz, A.; Bedolla-Guzmán, Y.; Cárdenas-Tapia, A.; Samaniego-Herrera, A. Mouse Eradication on San Benito Oeste Island, Mexico_Final Report; Grupo de Ecología y Conservación de Islas, A.C.: Ensenada, Mexico, 2016.

51. Gleeson, D.; Prada, D. Population Genetic Structure of Savannah Sparrow from San Benito Islands, Mexico; Ecogene, Landcare Research: Lincoln, New Zealand, 2010; p. 5.

52. Latofski-Robles, M.; Méndez-Sánchez, F.; Aguirre-Muñoz, A.; Jáuregui-García, C.; Koleff-Osorio, P.; González-Martínez, A.I.; Born-Schmidt, G.; Bernal-Stoopen, J.; Rendón-Hernández, E. Mexico's island biosecurity programme: Collaborative formulation and implementation. In Island Invasives: Scaling up to Meet the Challenge; Veitch, C.R., Clout, M.N., Martin, A.R., Russell, J.C., West, C.J., Eds.; Occasional Paper SSC no. 62; IUCN: Gland, Switzerland, 2019; pp. 484-488. 
53. Méndez Sánchez, F.A.; Latofski Robles, M.; Garciadiego San Juan, M.d.M.; Marichal González, A.E. Comunicación y Bioseguridad Insular para la Gobernanza Ambiental de las Islas Mexicanas. In Hacia la Sostenibilidad en América Latina: Aportes Desde la Divulgación de la Ciencia; Mena-Young, M., Ed.; Red de Popularización de la Ciencia, la Tecnología y la Innovación en América Latina y el Caribe (RedPop) y Centro de Investigación en Comunicación (CICOM), Universidad de Costa Rica: San José, Costa Rica, 2019; pp. 81-101.

54. Koleff, P.; Mendoza Alfaro, R.; Golubov, J.; González-Martínez, A.I.; Barrios-Caballero, Y.; De Jesús, S.D.J.; Ruiz-Utrilla, Z.P.; Méndez-Sánchez, F.; Latofski-Robles, M.; Garciadiego-San Juan, M.d.M.; et al. Invasive Alien Species in Mexico. In Invasive Alien Species; Wiley-Blackwell: Hoboken, NJ, USA, 2021; pp. 77-92.

55. Aguirre Muñoz, A.; Latofski Robles, M.; Maldonado Flores, I.Y.; Marichal González, A.E. Litearatura, arte y Conservación Ambiental en las islas de México; Grupo de Ecología y Conservación de Islas, A.C.: Ensenada, Mexico, 2020; pp. 18-24.

56. Born-Schmidt, G.; Servole, J.P.; Reyes-Gómez, V.; Hernández, E.R.; Chavira, E.A.; Barrientos, S.R.E. The Implementation of the Mexican Strategy on Invasive Species. In Invasive Alien Species; Wiley-Blackwell: Hoboken, NJ, USA, 2021; pp. $153-164$.

57. DIISE. The Database of Island Invasive Species Eradications. Available online: http:/ / diise.islandconservation.org (accessed on 25 October 2021).

58. Benkwitt, C.E.; Gunn, R.L.; Le Corre, M.; Carr, P.; Graham, N.A.J. Rat eradication restores nutrient subsidies from seabirds across terrestrial and marine ecosystems. Curr. Biol. 2021, 31, 2704-2711.e4. [CrossRef]

59. Graham, N.A.J.; Wilson, S.K.; Carr, P.; Hoey, A.S.; Jennings, S.; MacNeil, M.A. Seabirds enhance coral reef productivity and functioning in the absence of invasive rats. Nature 2018, 559, 250-253. [CrossRef]

60. Kurle, C.M.; Zilliacus, K.M.; Sparks, J.; Curl, J.; Bock, M.; Buckelew, S.; Williams, J.C.; Wolf, C.A.; Holmes, N.D.; Plissner, J.; et al. Indirect effects of invasive rat removal result in recovery of island rocky intertidal community structure. Sci. Rep. 2021, 11, 5395. [CrossRef]

61. Reyes-Arriagada, R.; Schlatter, R.P.; Hodum, P.J.; Rozzi, R. Seabirds and Island Communities: Biodiversity Awareness as a Tool for the Conservation of Insular Species. In Seabirds and Songbirds; Mahala, G., Ed.; Nova Science Publishers, Inc.: Hauppauge, NY, USA, 2015.

62. McClelland, P.J.; Coote, R.; Trow, M.; Hutchins, P.; Nevins, H.M.; Adams, J.; Newman, J.; Moller, H. The Rakiura Titi Islands Restoration Project: Community action to eradicate Rattus rattus and Rattus exulans for ecological restoration and cultural wellbeing. In Island Invasives: Eradication and Management, Proceedings of the International Conference on Island Invasives, Auckland, New Zealand, 8-12 February 2010; Veitch, C.R., Clout, M.N., Towns, D.R., Eds.; Occasional Paper of the IUCN Species Survival Commission No. 42; IUCN: Gland, Switzerland; CBB: Auckland, New Zealand, 2011; pp. 451-454.

63. Aguirre Muñoz, A.; Méndez Sánchez, F.; Latofski Robles, M.; Salizzoni Chávez, K. Mejoras en el marco legal para la conservación y restauración integral de las islas de México. In Reporte CESOP, Número 103, Febrero de 2017; Centro de Estudios Sociales y de Opinión Pública de la Cámara de Diputados: Mexico City, Mexico, 2017; pp. 19-23.

64. Matos, J.; Little, A.; Broome, K.; Kennedy, E.; Méndez Sánchez, F.; Latofski-Robles, M.; Irvine, R.; Gill, C.; Espinoza, A.; Howald, G.; et al. Connecting island communities on a global scale: Case studies in island biosecurity. West. N. Am. Nat. 2018, 78, 959-972. [CrossRef]

65. Millus, S.A.; Stapp, P. Interactions between seabirds and endemic deer mouse populations on Santa Barbara Island, California. Can. J. Zool. 2008, 86, 1031-1041. [CrossRef]

66. Millus, S.A.; Stapp, P.; Martin, P. Experimental control of a native predator may improve breeding success of a threatened seabird in the California Channel Islands. Biol. Conserv. 2007, 138, 484-492. [CrossRef]

67. Mallon, R. Naturalistic Approaches to Social Construction. Stanf. Encycl. Philos. 2019. Available online: https://plato.stanford. edu/archives/spr2019/entries/social-construction-naturalistic/ (accessed on 29 October 2021). 